\title{
Can the Ayurvedic pippali plant (Piper longum L.) be a good option for livelihood and socio-economic development for Indian farmers?
}

\author{
Padma Raj Gajurel*, Soyala Kashung, Sisibaying Nopi, Robert Panmei and Binay Singh
}

The pippali of Ayurveda botanically known as Piper longum L. is one of the economically valued plants, the fruits and roots of which are used widely in the preparation of traditional herbal medicines as well as in various modern drugs. The Ayurvedic medicine system has been heavily dependent on its use since time immemorial. Dried or powdered forms of the fruits and roots are sold at Rs 350 to $3000 \mathrm{per} \mathrm{kg}$, at the national and international markets. Supply of the raw materials is still dependent on the wild source as the existing cultivation and management practices are not adequate to fulfill the demand. If utilized, it may become one of the most important components of agroforestry systems in the tropical and subtropical warm humid climate of the country that may generate up to approximately $R s$ 130,000 as an additional income to the farmers.

Keywords: Agroforestry, cultivation techniques, livelihood, market demand, pippali.

WITH the fast-paced development worldwide, there is an increase in the outbreak of many diseases. As humans continue to depend on synthetic drugs, there has been a realization and renewed interest in plant-based medicines. With the recent spurt in demand for medicinal plants worldwide, more farmers are entering into this potential sector. India, with its diverse biogeographic area has a vast potential for the export of medicinal plants. The forests of the country are abound with important medicinal plants which are used widely by the traditional healers. About $22 \%$ of the herbal raw drugs in the country are produced through cultivation ${ }^{1}$. India with its centuries' old Ayurvedic-Unani history is home to about 7000 species of medicinal plants, of which only about 1178 species are used in trade ${ }^{1}$. Piper longum, commonly called as pipli, pippali, or long pepper belonging to the family Piperaceae is one such important medicinal plant. The dried female spikes (pippali) and roots (pippalimula) are the commercial parts of the plant which have been used in various formulations for treating different ailments like common cold, fever, indigestion, asthma, bronchitis, leprosy, cancer, etc. The species is known to contain more than 50 alkaloids and various other essential oils $^{2,3}$. Additionally, the species is used in household cooking as a spice and for seasoning foods. Despite its

The authors are with the Department of Forestry, North Eastern Regional Institute of Science and Technology, Nirjuli 791 109, India.

*For correspondence. (e-mail: prgajurel@gmail.com) wide range of medicinal values and high potentiality of industrial application, the species has not been managed properly. The climatic conditions of the Northeast and Southern plateau of India provide the best habitats for the luxuriant growth of the species. Hence its extensive domestication in various agroforestry systems could become one of the best options for livelihood enhancement. In view of its promotion for cultivation and management in the country, the commercial capability, present trading status and agro-techniques are discussed here.

\section{Pippali plant and its distribution}

Piper longum L. is a perennial low creeping root climber. It is a dioecious species with separate male and female individuals. The branches are dimorphic in nature where vegetative branches are creeping and rooting at nodes, and the fertile branches are erect with swollen nodes and without adventitious roots. The flowers are unisexual and borne on erect spikes. Fruiting spikes elongate up to $5 \mathrm{~cm}$. Drupes are densely aggregated, globose, black on maturing and characterized by aromatic smell and pungent taste (Figure 1).

The species is naturally distributed in the wild in the tropical and subtropical regions of the world such as Bangladesh, Bhutan, India, Indonesia, Myanmar, Nepal and Sri Lanka ${ }^{4}$. In India, the natural distribution is restricted to the hotter regions from Central Himalayas, to Assam, Arunachal Pradesh, Meghalaya, Sikkim, lower 
Table 1. Traditional medicinal uses of Piper longum in different Asian countries

\begin{tabular}{|c|c|c|c|}
\hline Country & Parts used & Uses & Selected references \\
\hline \multirow[t]{3}{*}{$\begin{array}{l}\text { India } \\
\text { (Indian Systems of Medicine) }\end{array}$} & Fruits & $\begin{array}{l}\text { Colds, asthma, arthritis, rheumatism, lumbago, } \\
\text { sciatica, epilepsy, indigestion, flatulence, } \\
\text { improves decongestion, antibiotic and analgesic } \\
\text { effects, toothache, gynaecological diseases } \\
\text { chronic bronchitis, intestinal distress }\end{array}$ & $8,21-23$ \\
\hline & Roots & $\begin{array}{l}\text { Diuretic, stimulant, sudorific, antidote against } \\
\text { snakebite and scorpion stings }\end{array}$ & 24 \\
\hline & Leaves, young shoots & Body/joint ache & 25 \\
\hline Nepal & Fruits & Rheumatic pain, cough, indigestion, bronchitis, fever & 26,27 \\
\hline Thailand & Dried unripe fruits & $\begin{array}{l}\text { Carminative, tonic, diarrhoea, expectorant, oxytocic } \\
\text { for postlabor, alleviate pain, fever and piles }\end{array}$ & 28,29 \\
\hline China & Fruits & $\begin{array}{l}\text { Stomach chills, vomiting, acid regurgitation, } \\
\text { headache and rhinitis }\end{array}$ & 24 \\
\hline
\end{tabular}
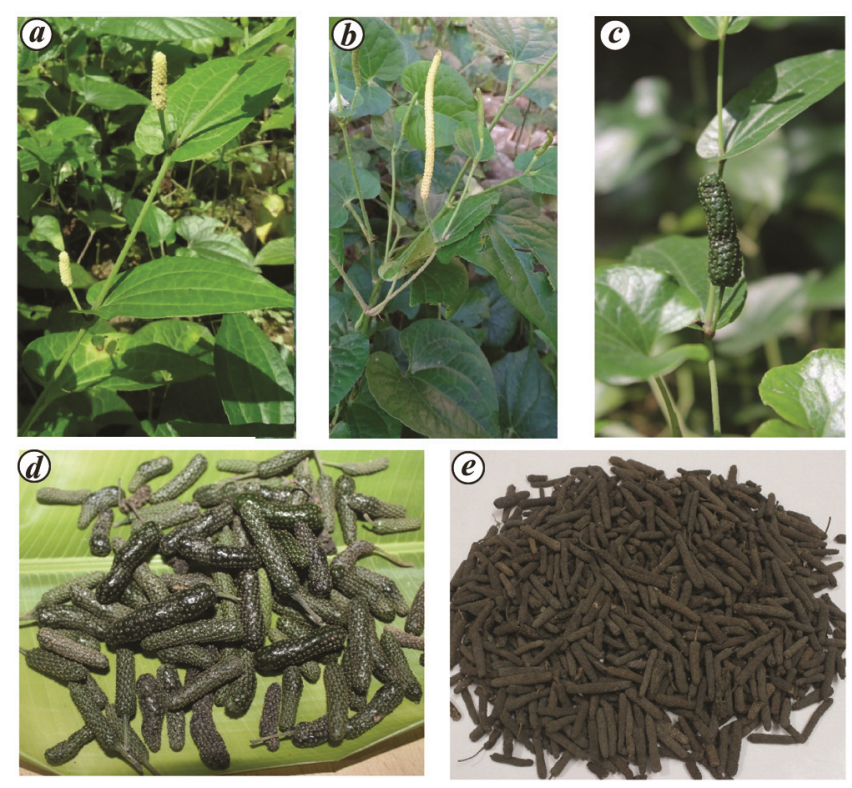

Figure 1. $\boldsymbol{a}$, Female flowering spike; $\boldsymbol{b}$, Male flowering spike; $\boldsymbol{c}$, Fruiting spike; $\boldsymbol{d}$ and $\boldsymbol{e}$, Fresh and dried fruits.

hills of West Bengal, Andhra Pradesh, parts of Western Ghats and Andaman \& Nicobar Islands ${ }^{4,5}$.

The species is reported to be cultivated at low elevations in some areas of Assam, Meghalaya, West Bengal, Uttar Pradesh, Madhya Pradesh, Maharashtra, Kerala, Karnataka and Tamil $\mathrm{Nadu}^{4,5}$. The species typically thrives well in areas with high rainfall and humidity and prefers well-drained sandy soil of $\mathrm{pH}$ range 5.5 to 8.5 with rich humus in shady areas.

\section{Traditional uses}

Apart from being used as a spice for flavouring foods, Piper longum is also used extensively throughout the world in various traditional medical practices. The importance of $P$. longum in the Indian traditional medicinal system has been described in ancient texts such as Cha- raka Samhita, Susruta Samhita, Vagbhata's Astangya Hrdayam, etc. ${ }^{6,7}$. The entire plant parts including the stem, roots, leaves, and fruits are reported to be used in the treatment of numerous ailments Table 1.

$P$. longum forms a significant part of the Ayurveda, Siddha and Unani system of medicines and is used for treating various ailments. It is one of the most preferred in the Indian Ayurvedic System, where the fruits and roots are used in more than 100 crude drug formulations which include cold (kaas), asthma, bronchitis, colic (shool), catarrhal fever (jwar), liver and spleen ailments (pleeha), piles (arsha), urinary tract diseases (prameh), leprosy (kushta), rheumatism (amavata), gastritis, dyspepsia, menstrual problems, haemorrhage during child birth, anorexia, gouts, paralysis, epilepsy, antidote against snake and scorpion bites ${ }^{8}$.

\section{Phytochemical properties and pharmaceutical values}

The plant contains a large number of alkaloids and other related compounds like volatile oil, starch, gums, resins, fatty oils and inorganic matter ${ }^{3,9}$. More than 50 various alkaloids are already reported from this plant. The most abundant alkaloids present is piperine, followed by methyl piperine, pipernonaline, piperettine, asarinine, pellitorine, etc. $^{3,10}$. Important lignans and esters contents of the plant include sesamin, pulvuatilon, tridecyldihydro-pcoumaarate, etc. ${ }^{11,12}$. The essential oil present in the fruits constitutes three major components, i.e. caryophyllene (17\%), pentadecane (15.8\%) and bisaboline $(11.2 \%)^{2}$. Major organic acids present comprise palmitic acid and tetrahydropiperic acid ${ }^{13}$.

Because of the occurrence of important bioactive principle and secondary metabolites, P. longum has gained worldwide attention for its various therapeutic uses. Some of its major pharmaceutical activities reported are anti-tumor activity, anti-diabetic activity, cardioprotective, hepatoprotective activity, antioxidant activity, 
immunomodulatory activity, anti-fertility activity, antivenom activity, etc.

\section{Market demand and supply of pippali in India}

Due to its diversified ethnomedicinal, ayurvedic and pharmaceutical applications, the market demand for pippali is rapidly rising both in national and international markets. The supply of traded pippali in India is mostly from the wild, collected from forests of Assam, West Bengal, Uttar Pradesh and Nepal. Additionally, a small proportion of the material is also contributed from small scale cultivated areas of Meghalaya, Madhya Pradesh, Maharashtra, Kerala, Karnataka and Tamil Nadu ${ }^{5,10}$. Our own field and market survey also revealed that collections and marketing of the fruits are mostly made from the wild collection from Arunachal Pradesh (foothills of Western parts of the state), Assam (bordering to Bhutan), Meghalaya, Bhutan and Bangladesh. All these collections from the wild are traded to the South Indian markets. Some companies that are engaged in trading of the species in India include Sathvabioactives Pvt Ltd, Enjay Marketing Services Pvt Ltd, BIOPREX/LABS, Mother Herbs Pvt Ltd, Nutramine Life Sciences, Alchemy Chemicals, M/S World Wide Enterprise, Genia Nature Herbs Pvt Ltd, Mazzy Exports, etc.

The domestic price of long pepper fruits varies from place to place and also suppliers. The products of the species mostly the fruits are sold at the rate of Rs 800 1500 per $\mathrm{kg}$ in Indian markets. The fresh, dried or powdered form of fruits and roots are exported to other countries with prices varying from Rs 350 to 3000 or more per $\mathrm{kg}$ (ref. 5). Some of the processed pippali products found in the Indian market include Chuturushana, Sragyada Churna, Ashta Churnam, Pulmoflex, Tabut Azaraqi, Tablet Munish, Majoon Lana, Majoon Falasefa, Jawarish Kamooni, Jawarish Bishasa, etc.

\section{International demand and supply}

Currently, Vietnam is the largest exporter of P. longum in the world with a $22.7 \%$ share in export followed by Brazil with $7.3 \%$ and Indonesia with 5.6\%. India ranks 4th among the countries exporting $P$. longum with a $1.9 \%$ share $^{14}$. USA, Austria, Australia, Africa, Canada, Russia, Philippines, Singapore, etc., are some of the countries where $P$. longum is being exported regularly. With proper cultivation technology and export mechanism, our country can aim to rise as a major global market for long pepper and other herbal products based industry.

\section{Adulterants}

Although $P$. longum is the major source of pippali, it has been found that the dried marketed fruits are a mixture of various other species of Piper. The most commonly used adulterant is the $P$. sylvaticum Roxb. and $P$. peepuloides Roxb., both of which are also grown in the habitats of $P$. longum.

\section{Potential of commercial cultivation and management of $P$. longum}

The above discussion clearly revealed that $P$. longum has a high market demand. However, at present, the species is cultivated and managed only in some selected regions in the country. Despite the suitable climatic requirements and availability of land, particularly in the northeastern region, $P$. longum is not found under large scale cultivation. An integrated effort from communities and government departments may boost its commercial cultivation in different parts of the country. Govt agencies like National Medicinal Plant Board offer support for large scale cultivation of various Piper species to Indian farmers. As the companies like Sathvabioactives Pvt Ltd, BIOPREX/ LABS, Nutramine Life Sciences, M/S World Wide Enterprise, Mazzy Exports, etc. directly buy the raw harvested products from the farmers, the cultivation may be promoted through buyback policies with these firms. Adoption of proper cultivation techniques selecting suitable habitats certainly leads to sufficient production of these raw materials that may fulfill the growing demands. The northeastern region of the country has a large volume of degraded forest lands where the species can be managed by the forest department involving the local communities to improve the productivity of the forest land.

Excessive collection of pippali from the wild has also resulted in the population reduction in the wild. There is an increasing demand in both the international and domestic markets promoting its systematic cultivation.

\section{Cultivation of $\boldsymbol{P}$. longum as an understorey crop in forest and agroforestry systems}

Presently, Non Timber Forest Produces (NTFPs) have gained importance in the management of forest, and particularly, medicinal plants with high commercial demands are being preferred. As per the Indian Forest Policy (1988), NTFPs which provide sustenance to the tribal population and other communities residing in and around forests should be managed to enhance their production with due regard to employment and income generation. $P$. longum as a highly valuable medicinal plant falls under such category. It is a shade-loving species with its creeping habit, easy to grow and manage, and having high market demand, could be one of the best choices for the forest department to introduce in the forest management schemes including Joint Forest Management (JFM). A vast volume of forest land in the region specifically as 
per the habitat preference (up to 1000 mean sea level) of the species, is available in the northeastern states without any countable productivity. They are either being simply left barren or covered with unwanted invasive species like Lantana camara, Mikania micrantha, Cuscuta reflexa, Pueraria spp., etc. On the other hand, these lands are capable of growing of various understorey crops with minimum soil and nutrient management. The total forest cover in the northeastern states of India is about $65.05 \%$ of the total geographical area. The rest of the land cover comes under crops, non-agricultural use or uncultivated lands ${ }^{15}$. The majority of the tribal communities of the region are mostly engaged in farming activities. However, due to the undulating topography and inaccessible terrain, there is less area under settled agricultural systems. To overcome these problems, people of the region have evolved their own traditional approaches to agricultural systems to facilitate and sustain themselves. With their diverse nature, the agroforestry practices have the potential to improve the livelihood of farmers by providing both economic production and ecological protection. Home gardens, jhum cultivation, cardamom and alder based farming system ${ }^{16}$, Zabo system of Kohima ${ }^{17}$, Bun system in Meghalaya and Apatani wetland rice cultivation integrated with fish culture ${ }^{18}$, are some of the examples of indigenous agroforestry systems widely practiced in the region. This shows that through some adjustments in the land-use strategies and cropping pattern, the farmers can adapt through changes in socioeconomic and environmental conditions.

As $P$. longum is found growing in the wild in northeastern states, it can be cultivated on a small to large scale in the foothills of Arunachal Pradesh, Mizoram, Nagaland and Meghalaya. It can be cultivated either as a monoculture crop or mixed crop with multipurpose trees such as Artocarpus heterophyllus, Albizia procera, Cinnamomum spp., Glyricidia sepium, Moringa oleifera, etc. Eventually, income from the multipurpose trees will provide extra profit to the farmers. If practiced with suitable cultivation practices, it can also be introduced in the secondary forests, degraded forests, etc. This plant has already been raised successfully as an intercrop with coffee and coconut plantation in some parts of Western Ghats ${ }^{19}$.

\section{Cultivation technology}

Seeds of pippali have very low germination capacity, and therefore the species is mainly cultivated through vegetative propagation. Usually stem cuttings with 3-5 nodes, or root tillers are used as propagation material (Figure 2). Propagation of the cuttings is usually carried out during March-April and plantation before the onset of monsoon.

Experimentation on propagation through stem cuttings of the plant conducted by us in Arunachal Pradesh showed a good result. Three distinct types of cuttings were made from the stem, i.e. cutting with one node, two nodes, and three nodes. The cuttings were raised in the nursery using poly bags with sand, soil and cow dung at a ratio of $2: 1: 1$. The planted cuttings were watered and monitored regularly. The emergence of new buds began after one month in all the three types of cuttings and grew successfully. The observation after 2 months revealed that the stem cuttings showed a good survival percentage with at least $70 \%$ in all the three types of cuttings indicating regeneration potentiality through the stem as in other Piper species. Though all the three cutting types showed good results, it would be recommendable to use the threenode cutting for commercial cultivation as this will promote the production of higher number of shoots capable of producing good number of fruiting spikes. However, during selection, one must select the female plant. Production of fruits without male counterpart is already reported in Piper and had also been observed in P. longum by us. However, for ascertaining healthy fruits, at least $5 \%$ of male plants should be raised.

The well established seedlings are transplanted in the field at $1 \times 1 \mathrm{~m}$ under mono-cropping or $2 \times 2 \mathrm{~m}$ distance in mixed cropping. Manuring of the plantation area with Farm Yard Manure (FYM) or any other organic manure can be done during the first year of the plantation before the onset of monsoon. Irrigation is usually done 2-3 times a week depending on soil quality and weather conditions. Growth of weeds must be avoided in the plantation. Raising of cuttings should be initiated between March and April which can then be transplanted in the field during May-July.
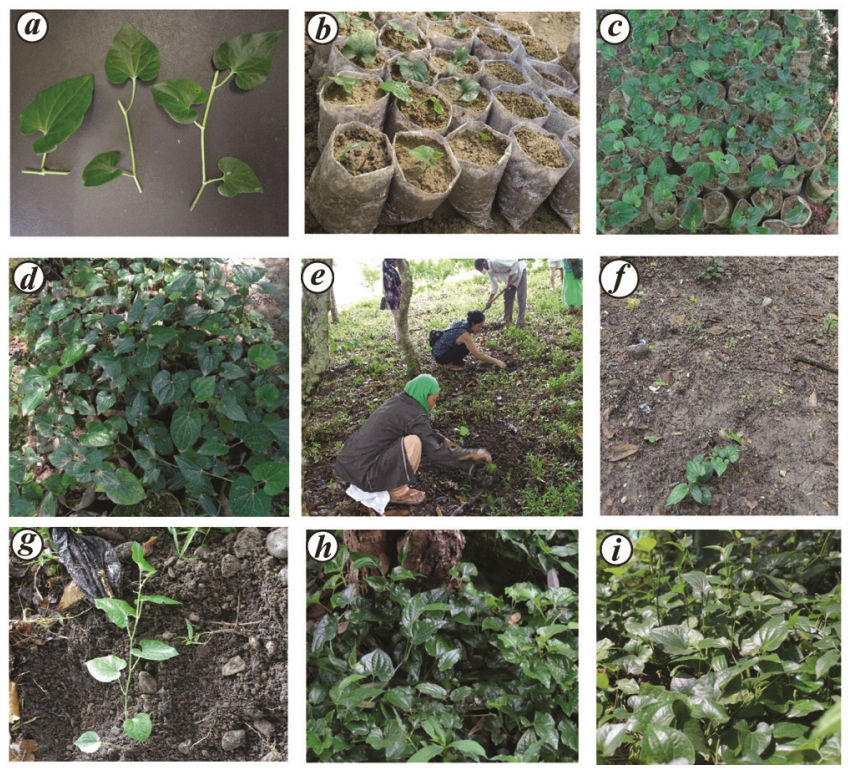

Figure 2. $\boldsymbol{a}$, Cuttings with 1,2 and 3 nodes; $\boldsymbol{b}$, Cuttings in polybags; $\boldsymbol{c}$, Two months old cuttings; $\boldsymbol{d}$, Three months old and ready for plantation cuttings; $\boldsymbol{e}$, Transplantation of cuttings in North Eastern Regional Institute of Science and Technology (NERIST) campus; $\boldsymbol{f}$, Transplanted cuttings at $2 \times 2 \mathrm{~m}$ distance; $\boldsymbol{g}$, Transplanted cuttings; $\boldsymbol{h}$ and $\boldsymbol{i}$, Established flowering and fruiting plants in NERIST campus. 


\section{Harvesting and yield}

The flowering of the plant starts after 2 to 3 months from the cuttings raised from fertile shoots. Generally, P. longum produces flowers from August to October, after 4-5 months of planting, and fruits are ready to be harvested 2-3 months after spike formation, which would be mostly from December to February. The fruits are preferably harvested just before ripening to retain the best quality.

In mixed cropping patterns, about $66 \mathrm{~kg} / \mathrm{ha}$ dried spikes can be harvested during the first year which will rise to about $166 \mathrm{~kg} / \mathrm{ha}$ from the second year onwards. The yield eventually decreases after the fourth year and by the fifth year it becomes economically unfeasible, therefore the plants need to be replanted. The stem and roots can also be harvested for producing a product called 'pippalimula' or 'piplamool'. The root is traded based on their grading. Grade I comprises of thick roots and underground stem which are sold at a higher price as compared to Grade II and Grade III which are composed of thin roots, stem and broken fragments ${ }^{20}$.

\section{Economy and employment generation}

In mixed cropping of introducing the species in any agroforestry system, the farmer can earn a minimum of about Rs 50,000 per hectare as additional income per year. Combining with other crops in the agroforestry farming system, the profit may increase as per the nature of the intermixed crop. Unlike most other commercial crops, farmers can reap the benefits right from the first year of planting as the plant starts producing fruits within 6-7 months of its planting. An estimation of the net income per hectare is as shown below.

Net income from fruiting spikes (@Rs 800/kg) in an agroforestry system

Total plants that can be accumulated $=2500$ per hectare

Income in first year $=$ Rs 52,800

$[2500 \times 8$ spikes $=20,000$ spikes (approx. 8 spikes/ plant $)=66 \mathrm{~kg}(1 \mathrm{~kg}=300$ spikes $)]$

Income from second year to fourth year $=\mathrm{Rs} 132,800$

$[2500 \times 20$ spikes $=50,000$ spikes (approx. 20 spikes/ plant $)=166 \mathrm{~kg}]$.

It is also estimated that through monocropping with reducing the spacing below $1 \mathrm{~m} \times 1 \mathrm{~m}$, a farmer may also earn a net income of Rs 100,000 to 150,000 per hectare 5 .

Large scale plantation of $P$. longum will play a considerable and increasing role in fulfilling the supply gap for industrial demands. It will also provide employment opportunities that can make a difference in rural areas with weak labour markets. The various activities required in the nurturing of the plants like nursery management, plantation, plant management, harvesting, grading and drying and marketing will thereby play a vital role in economy and manpower generation.

\section{Conclusion}

Medicinal plants with regular market demands always provide better livelihood options for the farmers. However, due to the lack of understanding of their marketing demand and cultivation techniques, many of the potential medicinal herbs are yet to be recognized for large scale farming. P. longum is one of the best crops that can be cultivated easily with minimum efforts for generation of good revenue. Due to its shade-loving nature and warm humid climatic requirement, it can be introduced as one of the understorey crops in different agroforestry systems where a farmer may earn about Rs 50,000-150,000 per hectare as an additional income along with various other crops of silvicultural and horticultural importance. Once large scale cultivations are targeted, it may also promote self-employment opportunities for the farmers through processing and marketing of the products. Various Govt departments can take an integrated approach for promotion of the commercial cultivation of this crop involving the local mass, particularly in the northeastern region of the country.

1. Anon., Indian medicinal plants - Fact sheet. National Medicinal Plant Board, 2019; https:/www.nmpb.nic.in/content/medicinalplants-fact-sheet

2. Lawrence, B. M., Progress in essential oils: long pepper oil. Perfum. Flavor., 2015, 40, 42-44.

3. Gani, H. M. O., Hoq, M. O. and Tamanna, T., Ethnomedicinal, phytochemical and pharmacological properties of Piper longum (Linn). Asian J. Med. Biol. Res., 2019, 5(1), 1-7.

4. Gajurel, P. R., Rethy, P., Kumar, Y. and Singh, B., Piper species (Piperaceae) of North-East India (Arunachal Pradesh), Bishen Singh Mahendra Pal Singh, Dehra Dun, India, 2008, pp. 50-52.

5. Devi, J. and Das, R., Pipli cultivation: a potential income generating option. J. Med. Plants Stud., 2018, 6(6), 149-151.

6. Charaka and Drindhabala, Charaka Samhita (ed. Trikamji, V. A. Y.), Chaukambha Sanskrit Sansthan, Varanasi, 2001, p. 738.

7. Susruta, Susruta Samhita-A Ayurveda Tattva Sandipika (ed. Ambikadutta, S. K.), Chaukhamba Sanskrit Sansthan, Varanasi, 2001, p. 879.

8. Kothari, N., Bedre, R., Dorle, K., Kolpakwar, S. and Deshmukh, S., Conceptual study of judicious use of pippali as a broadspectrum antibiotic in various chest infections. World J. Pharm. Res., 2018, 7(17), 644-650.

9. Nandkarni, K. M., Indian Materia Medica, Bombay Popular Prakashan, India, 1989, vol. 1, pp. 965-969.

10. Abbasi, H. and Kabir, H. A., Traditional miraculous drug Piper longum: review. Int. J. Sci. Res. Rev., 2018, 7(11), 369-377.

11. Sankaracharya, N. B., Rao, L. J., Naik, J. P. and Nagalakshmi, S., Characterization of chemical constituents of Indian Long Pepper. J. Food Sci. Tech., 1997, 34(1), 73-75.

12. Sharma, R. K., Rathore, Y. K. S. and Kumar, S., Chemical examination of dried fruits of Pippali (P. longum). J. Med. Plants Res., 1983, 4(4), 63-65. 
13. Dutt, C. P., Banerjee, N. and Roy, D. N., Lignans in the seeds of Piper longum. Phytochemistry, 1975, 14, 2090-2092.

14. Anon., Long pepper global import and top importing countries 2020; https://www.tridge.com/intelligences/long-pepper/import

15. Anon., India State of Forest Reports, Forest Survey of India, MoEF, Dehradun, India, 2019; https://fsi.nic.in/isfr-volumei?pgID=isfr-volume-i

16. Sharma, R., Sharma, E. and Purohit, A. N., Dry matter production and nutrient cycling in agroforestry systems of cardamom grown under the Alnus and natural forest. Agroforest. Syst., 1994, 27, 293-306.

17. Das, A., Munda, G. C., Ghosh, P. K., Patel, D. P., Ngachan, S. V. and Tripathi, A. K., Resource conservation through indigenous farming systems in North East India. In Proceedings of the 4th World Congress on Conservation Agriculture, NASC Complex, New Delhi, India, 4-7 February 2009, pp. 355-356.

18. Das, A. et al., Natural resource conservation through indigenous farming systems: wisdom alive in North East India. Indian J. Tradit. Know., 2012, 11(3), 505-513.

19. Manoj, P., Soniya, E. V., Banerjee, N. S. and Ravichandran, P., Recent studies on well-known spice, Piper longum Linn. Nat. Prod. Radiance, 2004, 3, 222-227.

20. Kumar, S., Kamboj, J., Suman and Sharma, S., Overview for various aspects of the health benefits of Piper longum Linn. fruit. J. Acupunct. Meridian Stud., 2011, 4(2), 134-140.

21. Ashalata, M. and Sannappanawar, R. B., A review article on pippali (Piper longum Linn). Int. Ayurvedic Med. J., 2015, 3(9), 2841-2849.

22. Vinodoni, R., Hazel, A. M. A., Sundaram, M. M. and Banumathi, V., Therapeutic potency of Siddha herbomineral preparation SiddhadhiEnnai on gynaecological diseases - a review. World J. Pharm. Pharm. Sci., 2018, 7(10), 969-979.

23. Marjana, Mini, P. P., Remyakrishnan, C. R. and Baiju, E. C., Ethnomedicinal flowering plants used by Kurumas, Kurichiyas and
Paniyas tribes of Wayanad district of Kerala, India. Int. J. Biol. Res., 2018, 3(3), 1-8.

24. Fern, K., Fern, A. and Morris, R., Useful Tropical Plants Database; http://tropical.theferns.info/ (accessed on 12 March 2019).

25. Kashung, S., Gajurel, P. R. and Singh, B., Ethnobotanical uses and socio-economic importance of climbing species in Arunachal Pradesh, India. Plant Sci. Today, 2020, 7(3), 371-377.

26. Singh, A. G., Kumar, A., Tewari, D. D. and Bharati, K. A., New ethnomedicinal claims from Magar community of Palpa district, Nepal. Indian J. Tradit. Know., 2018, 17(3), 499-511.

27. Singh, A. G. and Kumar, A., Ethnomedicinal aspects of climbing plants of Palpa district, Nepal. Trop. Plant Res., 2017, 4(2), 307313.

28. Sireeratawong, S., Itharat, A., Lerdvuthisopon, N., Piyabhan, P., Khonsung, P., Boonraeng, S. and Jaijoy, K., Anti-inflammatory, analgesic, and antipyretic activities of the ethanol extract of Piper interruptum Opiz. and Piper chaba Linn. ISRN Pharmacol., 2012, 2012, 480265 .

29. Naz, T., Mosaddik, A., Rahman, M. M., Muhammad, I., Haque, M. E. and Cho, S. K., Antimicrobial, antileishmanial and cytotoxic compounds from Piper chaba. Nat. Res. Prod., 2012, 26, 979986.

ACKNOWLEDGEMENTS. The financial support received from Department of Biotechnology, Govt of India under the project entitled 'Bioresource and Sustainable Livelihoods in North East India' (Project No. BT/01/17/NE/TAX) is duly acknowledged. We also express our thanks to the Director, and Head, Department of Forestry for providing all the necessary facilities.

Received 16 November 2020; revised accepted 23 February 2021

doi: $10.18520 / \mathrm{cs} / \mathrm{v} 120 / \mathrm{i} 10 / 1567-1572$ 